\title{
Productivity and Efficiency of Precision Farming: The Case of Czech Cereal Production
}

\author{
Lukáš Čechura ${ }^{1}$, Zdeňka Žáková Kroupová ${ }^{1}$, Vladimír Kostlivý ${ }^{2}$, Michaela Lekešová2 \\ ${ }^{1}$ Faculty of Economics and Management, Czech University of Life Sciences Prague, Czech Republic \\ ${ }^{2}$ Institute of Agricultural Economics and Information, Prague, Czech Republic
}

\begin{abstract}
The paper deals with the sources of competitiveness of Czech cereal production by considering precision farming technology and employing micro-level data collected in the FADN database for the period 2005-2018. The analysis is based on the stochastic frontier modelling of an input distance function in the specification of the four-component model, which currently represents the most advanced approach to technical efficiency analysis. To provide a robust estimate of the model, the paper employs methods which control for the potential endogeneity of netputs in the four-step estimation procedure. Furthermore, the total factor productivity change is calculated using the Törnqvist-Theil index. The results reveal that Czech cereal producers took great advantage of their production possibilities and experienced technological progress, which contributed considerably to productivity dynamics and consequently to an increase in their competitiveness. Precision farming, which is associated with a large number of innovations reflected in technological change and optimal resource use, contributed to higher technical efficiency connected with cost savings in Czech cereal production.
\end{abstract}

\section{Keywords}

Total factor productivity, technical efficiency, precision farming, technology, cereal production.

Čechura, L., Žáková Kroupová, Z., Kostlivý, V. and Lekešová, M. (2021) "Productivity and Efficiency of Precision Farming: The Case of Czech Cereal Production", AGRIS on-line Papers in Economics and Informatics, Vol. 13, No. 3, pp. 15-24. ISSN 1804-1930. DOI 10.7160/aol.2021.130302.

\section{Introduction}

The rising demand for agricultural products, combined with the need for environmental protection and climate change challenges, has put pressure on agriculture to find innovative farming practices. Precision farming, which is a modern farming management concept using digital techniques to monitor and optimise agricultural production processes (Schrijver et al., 2016), is a way to meet the challenges of sustainable agriculture in the 21 st century.

In the last few years, precision farming has been gaining attention in the European Union, although the definition of precision farming can be dated back to the late 1990s. According to the National Research Council (1997), precision farming is like "a management strategy that uses information technologies to bring data from multiple sources to bear on decisions associated with crop production". However, precision farming is not just about crop production (see e.g. Lovarelli et al., 2020). It is a farming management concept based upon observing, measuring and responding to interand intra-field variability in crops or in aspects of animal rearing (Zarco-Tejada et al., 2014). More simply, it is a way to apply the right treatment in the right place at the right time (Gebbers and Adamchuk, 2010). Precision farming utilizes information technology, sensor technologies, satellite technology, Artificial Intelligence (AI), and the Internet of Things for enhancing all functions and services of the agriculture sector (Khanal et al., 2017 and Schrijver et al., 2016). Moreover, precision farming implements techniques and technologies that highlight the relevance of integrating specific ecological principles and biodiversity management procedures into agrospace management, while optimizing inputs to maximize yields (Loures et al., 2020). For example, machine learning technology can be integrated with remote sensing for accurate forecasting of crop production and estimation of nitrogen levels in precision farming (Torky and Hassanein, 2020). This data-driven agriculture can be viewed as one of the main strategies and concepts proposed to increase production 
efficiency while decreasing its environmental impact (Foley et al., 2011).

Economic as well as environmental studies (Zhang et al., 2002; Zarco-Tejada et al., 2014; Mintert et al., 2016; Schrijver et al., 2016; Balafoutis et al., 2017; Jat et al., 2018; Finger et al., 2019; Soto et al., 2019; Loures et al., 2020) have emphasised multiple benefits from precision farming. Focusing on cereal production, the benefits of precision farming include reducing costs by only applying fertilizers where they are required, based on soil samplings and analysis of the yield data, improving the management of water resources, and optimizing performance through automated harvesting practices (Cisternas et al., 2020). In conventional farming, on the contrary, fertilizers are applied uniformly over fields at certain times during the year. This leads to over-application in some places, with an environmental cost (water pollution), and under-application in others, with an economic cost (reduction of crop yields). Similarly, precision farming uses herbicides and pesticides in specific areas where and when they are needed. Furthermore, controlled traffic methods reducing soil compaction by heavy machinery bring additional economic as well as environmental cost reductions (Zarco-Tejada et al., 2014). The comparative analysis of precision and conventional maize and wheat production presented by Jat et al. (2018) reveals a higher yield of both kinds of cereals and a lower cost in precision farming compared to conventional. That is, precision farming contributes to field efficiency growth (Balafoutis et al., 2017). The yield increase is a result of the compound effect of improved soil health, better water regimes, reduced weed population, and specific nutrient management. The lower cost of production is mainly due to lower costs for tillage, irrigation and weeding (Jat et al., 2018).

The positive effects of precision agriculture are reflected in the efficiency of the conversion of inputs into outputs and in the competitiveness of agricultural producers. Interestingly, in economic research there is a gap in precision farming's technical efficiency and productivity analysis. Moreover, little research has been carried out in the Czech Republic on this topic. The research on technical efficiency and productivity analysis is predominantly devoted to conventional farming. For example, Čechura et al. (2015) analysed the factors determining changes in total factor productivity (TFP) in Czech cereal production based on the Törnqvist-Theil index and the fixed management model. Their results highlighted the role of technological change in productivity growth and recommended targeting agricultural support toward modernization and innovation in the cereals sector. Kostlivý et al. (2020) investigated the technical efficiency of Czech crop-producing farms based on the stochastic frontier true random effect model, taking into account the heterogeneity of farms, and pointed out that innovative crop farms are likely to be more productive. Bokusheva and Čechura (2017) evaluated the TFP and the technical efficiency of crop farms in six member states of the European Union (the Czech Republic, among others) based on the four-error component model introduced by Kumbhakar et al. (2014). Their results confirmed the contribution of technological progress to TFP growth and indicated that sample farms can greatly reduce their costs for producing the same volume of outputs (by $15 \%$ in the case of Czech farms evaluated on the sample mean). In crop production, the same four-error component model, which is the most advanced approach to estimating technical efficiency, was also applied by Lien et al. (2018), who analyzed Norwegian crop-producing farms, Addo and Salhofer (2019), who focused on Austrian crop farms, and Pisulewski and Marzec (2019), who investigated Polish crop farms. The efficiency literature deals with Less Favoured Areas (LFA) and organic farming to a lesser extent. For example, Rudinskaya et al. (2019) evaluated the differences in Czech farms' technical efficiency resulting from their location in LFA using a stochastic frontier analysis (SFA) and true random effects model. Madau (2007) applied SFA to estimate technical efficiency in a sample of Italian organic and conventional cereal farms. The results of these studies agree that organic farms and farms situated in LFA tend to overuse resources compared to bestpractice farms.

The aim of the paper is to evaluate differences in productivity and efficiency between the group of farmers who use the technology of precision farming and the group of farmers who use standard conventional farming technology. In particular, the study aims to fill the gap in the literature by providing a deep insight into the sources of competitiveness of precision farming by employing new advances in productivity and efficiency analysis and using individual farm data (FADN) with information on precision farming.

The paper is organized as follows: The next section introduces data and a model specification and describes the empirical strategy; then the results 
and discussion are presented; and the final section summarizes our findings and provides concluding remarks.

\section{Materials and methods}

The analysis is based on the currently most advanced approach to investigating technical efficiency, introduced by Kumbhakar et al. (2014) and Colombi et al. (2014). The four-error component model, called the generalized true random effects model (GTRE) by Tsionas and Kumbhakar (2014), allows for the estimation of the persistent and transient parts of technical inefficiency from the same data while considering latent heterogeneity. The distinction between persistent and transient technical inefficiency has significant analytical and political implications because these parts of overall technical inefficiency may vary across farms, for various reasons, and can be corrected by more or less fundamental changes. As Njuki and Bravo-Ureta (2015) have mentioned, persistent technical inefficiency could arise due to the presence of rigidity within an organization and production process. In other words, it reflects structural problems in the organization of the production process or a systematic lack of managerial skills (Filippini and Greene, 2016) and is unchangeable without a new policy or change in the ownership and management of companies (Kumbhakar et al., 2014). Transient inefficiency arises as a result of non-systematic managerial failures that can be resolved in the short term (Filippini and Greene, 2016). It is a result of shocks associated with new production technologies, human capital, and learning-by-doing (Pisulewski and Marzec, 2019).

In this study, the GTRE specification is applied on the input distance function (IDF), which measures the largest factor of proportionality $\rho$ by which the input vector $x$ can be scaled down in order to produce a given output vector $y$ with the technology existing at a particular time $t$ (Caves et al., 1982), formally: $D^{I}(y, x, t)=\max \{\rho: x / \rho \in L(y)\}$. According to Caves et al. (1982), if $D^{I}(y, x, t)=1$, the given output vector $y$ is produced with the minimum amount of inputs at a given time and with the given technology, and a farm is technically efficient.

Implying the homogeneity property of the IDF (Knox Lovell et al., 1994) that is imposed by normalising all the inputs by one input, introducing statistical error term $\left(v_{i t}\right)$ and latent heterogeneity $\left(\mu_{i}\right)$, and replacing $\ln D_{i \mathrm{t}}^{I}$ with inefficiency terms: persistent technical inefficiency $\left(\eta_{i}\right)$ and transient technical inefficiency $\left(u_{i t}\right)$, that is $\eta_{i}+u_{i t}=\ln D_{i t}^{I}$, the translog IDF takes the form of the GTRE model of M-outputs $(y)$, J-inputs $(x)$, and time $(t)$ :

$$
\begin{aligned}
-\ln x_{1 i t} & =\alpha_{0}+\sum_{m=1}^{M} \alpha_{m} \ln y_{m, i t}+ \\
& +\frac{1}{2} \sum_{m=1}^{M} \sum_{n=1}^{N} \alpha_{m n} \ln y_{m, i t} \ln y_{n i, t}+ \\
& +\sum_{m=1}^{M} \sum_{j=2}^{J} \gamma_{m j} \ln y_{m, i t} \ln \tilde{x}_{j, i t}+ \\
& +\sum_{j=2}^{J} \beta_{j} \ln \tilde{x}_{j, i t}+ \\
& +\frac{1}{2} \sum_{j=2}^{J} \sum_{k=2}^{K} \beta_{j k} \ln \tilde{x}_{j, i t} \ln \tilde{x}_{k, i t}+ \\
& +\delta_{t} t+\frac{1}{2} \delta_{t t} t^{2}+\sum_{m=1}^{M} \delta_{m t} \ln y_{m, i t} t+ \\
& +\sum_{j=2}^{J} \delta_{j t} \ln \tilde{x}_{j, i t} t+\mu_{i}-\eta_{i}-u_{i t}+v_{i t},
\end{aligned}
$$

where subscripts $i$, with $i=1,2, \ldots, N$, and $t$, with $t=1, \ldots, T$, refer to a certain farm and time (year), respectively. $\alpha, \beta, \gamma$, and $\delta$ are vectors of the parameters to be estimated. The symmetry restrictions imply that $\beta_{j k}=\beta_{k j}$ and $\alpha_{m n}=\alpha_{n m}$. The time trend included in the IDF allows for capturing the joint effects of embedded knowledge, technology improvements, learning-by-doing, and input quality improvements (see Čechura et al., 2017). Finally, the error term consists of: $\quad v_{i t} \sim N\left(0, \sigma_{v}^{2}\right), \quad u_{i t} \sim N^{+}\left(0, \sigma_{u}^{2}\right), \quad \eta_{i} \sim N^{+}\left(0, \sigma^{2}{ }_{\eta}\right)$, and $\mu_{i} \sim N\left(0, \sigma_{\mu}^{2}\right)$.

In addition to the estimation of technical efficiency, the specification of the production technology in the translog IDF also allows for calculation of the total factor productivity change using the Törnqvist-Theil index (TTI), defined as the ratio of the revenue-share weighted geometric mean of individual outputs to the cost-share weighted geometric mean of individual inputs (Coelli et al., 2015). Formally, the logarithmic form of TTI is given by (Bokusheva and Čechura, 2017):

$$
\begin{aligned}
\ln \left(\frac{T F P_{i t}}{T F P_{i(t-1)}}\right) & =\frac{1}{2} \sum_{m=1}^{M}\left(R_{i t, m}+R_{i(t-1), m}\right)\left(\ln y_{i t, m}-\ln y_{i(t-1), m}\right)- \\
& -\frac{1}{2} \sum_{j=1}^{J}\left(S_{i t, j}+S_{i(t-1), j}\right)\left(\ln x_{i t, j}-\ln x_{i(t-1), j}\right),(2)
\end{aligned}
$$

where $R_{m}=\frac{p_{m} y_{m}}{\sum_{m=1}^{M} p_{m} y_{m}}$ are output revenue shares and $S_{j}=\frac{w_{j} x_{j}}{\sum_{j=1}^{J} w_{j} x_{j}}$ are input cost shares.

Following Diewert (1976), the TTI can be derived using the parameter estimates of the translog IDF in (1) as the sum of three components: scale effect $\left(S C=\ln l_{i t}\right)$, technical efficiency effect $\left(T E=\ln v_{i t}\right)$, and technological change $\left(T C=\ln \tau_{i t}\right)$ effect:

$\ln T F P_{i t}=\ln v_{i t}+\ln v_{i t}+\ln \tau_{i t}$.

The scale effect, capturing the contribution 
of economies of scale, or in other words, of falling average costs as a result of the increasing quantity of output (Mankiw, 2009), is measured as:

$$
\begin{aligned}
\ln \iota_{i t} & =\frac{1}{2} \sum_{m=1}^{M}\left[\left(\zeta_{i t, m}+\bar{\zeta}_{m}\right)\left(\ln y_{i t, m}-\overline{\ln x_{m}}\right)+\right. \\
& \left.+\bar{\zeta}_{m} \overline{\ln y_{m}}-\overline{\zeta_{t t, m} \ln y_{l t, m}}\right]
\end{aligned}
$$

where $\zeta_{i t, m}=\left(1-R T S^{-1}\right) \frac{\partial \ln D^{I}\left(x_{i t}^{*}, y_{i t}, t\right)}{\partial \ln y_{i t, m}}$

and $R T S^{-1}=\sum_{m=1}^{M}-\frac{\partial \ln D^{I}\left(x_{i t}^{*}, y_{i t}, t\right)}{\partial \ln y_{i t, m}}$

The technical efficiency effect, associated with movements towards (or away from) the frontier technology, is measured as:

$\ln v_{i t}=\ln T E_{i t}-\overline{\ln T E_{l t}}$,

where $T E_{i t}=\exp \left(-\hat{u}_{i t}\right)$.

Finally, the technological change component, which captures the improvement in the farm's ability to produce the same amount of output using fewer inputs due to the shift of the transformation function (frontier) over time (Chambers, 1988), is expressed as:

$$
\ln v_{i t}=\varphi_{i t}-\overline{\varphi_{i t}},
$$

where $\quad \varphi_{i t}=-\frac{\partial \ln D^{I}\left(x_{i t}^{*}, y_{i t}, t\right)}{\partial \ln t}$

(Bokusheva

and Čechura, 2017).

The estimation of the GTRE model is undertaken as a multistep procedure. We follow Kumbhakar et al. (2014) and rewrite the model in (1) as:

$$
\begin{aligned}
-\ln x_{1 i t} & =\alpha_{0}^{*}+\sum_{m=1}^{M} \alpha_{m s} \ln y_{m, i t}+ \\
& +\frac{1}{2} \sum_{m=1}^{M} \sum_{n=1}^{N} \alpha_{m n} \ln y_{m, i t} \ln y_{n i, t}+ \\
& +\sum_{m=1}^{M} \sum_{j=2}^{J} \gamma_{m j} \ln y_{m, i t} \ln \tilde{x}_{j, i t}+ \\
& +\sum_{j=2}^{J} \beta_{j s} \ln \tilde{x}_{j, i t}+ \\
& +\frac{1}{2} \sum_{j=2}^{J} \sum_{k=2}^{K} \beta_{j k} \ln \tilde{x}_{j, i t} \ln \tilde{x}_{k, i t}+ \\
& +\delta_{t s} t+\frac{1}{2} \delta_{t t} t^{2}+\sum_{m=1}^{M} \delta_{m t} \ln y_{m, i t} t+ \\
& +\sum_{j=2}^{J} \delta_{j t} \ln \tilde{x}_{j, i t} t+\alpha_{i}+\varepsilon_{i t}
\end{aligned}
$$

where $\alpha_{0}^{*}=\alpha_{0}-E\left(\eta_{i}\right)-E\left(u_{i t}\right), \alpha_{i}=\mu_{i}-\left(\eta_{i}-E\left(\eta_{i}\right)\right)$ and $\varepsilon_{i t}=v_{i t}-\left(u_{i t}-E\left(u_{i t}\right)\right)$.

This specification ensures that $\alpha_{i}$ and $\varepsilon_{i t}$ have zero mean and constant variance. To obtain consistent estimates of technology, as well as productivity and efficiency measures, we use methods which control for the potential endogeneity of netputs, which arises when one or more explanatory variables are correlated with the error term. Following Bokusheva and Čechura (2017), we applied a four-step procedure. In step 1, the two-step system generalized method of moments (GMM) estimator (Arellano and Bover, 1995; Blundell and Bond, 1998) is used to obtain consistent estimates of the IDF parameters. The system GMM, which resolves the endogeneity problem and the problem of weak instruments, estimates a model in differences and levels and employs two types of instruments: level instruments for the differenced equations and lagged differences for the equations in levels (Arellano and Bover, 1995). In step 2, residuals are used from the system GMM level equation to estimate a random effects panel model employing the generalized least squares (GLS) estimator. In step 3, the transient technical inefficiency, $u_{i t}$, is estimated using the standard stochastic frontier technique with assumptions: $v_{i t} \sim N\left(0, \sigma^{2}{ }_{v}\right)$, $u_{i t} \sim N^{+}\left(0, \sigma_{u}^{2}\right)$. In step 4 , the persistent technical inefficiency, $\eta_{i}$, is estimated using the stochastic frontier model with the following assumptions: $\mu_{i} \sim N\left(0, \sigma_{\mu}^{2}\right), \eta_{i} \sim N^{+}\left(0, \sigma_{\eta}^{2}\right)$, and the overall technical efficiency (OTE) is quantified based on Kumbhakar et al. (2014): $O T E_{i t}=\exp \left(-\hat{\eta}_{i}\right) * \exp \left(-\hat{u}_{i t}\right)$. All these estimates are done in the SW STATA 14.0.

The analysis uses a panel data set drawn from the Farm Accountancy Data Network (FADN) database and represents the period 2005 till 2018. For the estimation of the IDF in this study, we define the following vectors of outputs and inputs: Cereals output represents the value of the total crops output; other crops output is the difference between the value of total crops output minus cereals output; and other farm output is the difference between the value of farm total output and the value of total crops output. Land is expressed in hectares of farm Utilised Agricultural Area (UAA); capital is represented by capital depreciation and contract work; labour is measured in an Annual Working Unit (AWU, where one AWU represents 1800 working hours per year); and material is defined as total intermediate consumption.

Moreover, we normalize all variables in logarithm by their sample mean. This procedure ensures that we can interpret the first-order parameters as output elasticities and input cost shares, evaluated on the sample mean, respectively. In addition, we rejected farms with less than 3 consecutive years of observations, to comply with the requirements of the system-GMM estimator.

\section{Results and discussion}

Table 1 provides a parameters estimate of the input distance function for Czech cereal producers. The results show that the majority of the first- 
order parameters are statistically significant even at the $1 \%$ significance level. Moreover, the estimates meet the theoretical assumptions. Specifically, the results of fitted distance functions evaluated at the sample means are non-increasing in outputs and non-decreasing in inputs. Moreover, the quasi-concavity assumption of the input distance functions with respect to inputs is also met by the estimate. Finally, the AR(2) test and Hansen's J-test statistics indicate the validity of model estimates.

\begin{tabular}{|c|c|c|c|}
\hline Variable & Coefficient & Std. Err. & p-value \\
\hline Cereals & -0.516 & 0.024 & 0.000 \\
\hline Other crops & -0.274 & 0.019 & 0.000 \\
\hline Other farm output & -0.139 & 0.012 & 0.000 \\
\hline Land & 0.126 & 0.063 & 0.046 \\
\hline Labour & 0.143 & 0.040 & 0.000 \\
\hline Capital & 0.158 & 0.028 & 0.000 \\
\hline Cereals $^{2}$ & -0.101 & 0.034 & 0.004 \\
\hline Other crops ${ }^{2}$ & -0.082 & 0.012 & 0.000 \\
\hline Other farm output ${ }^{2}$ & -0.048 & 0.006 & 0.000 \\
\hline Cereals* Other crops & 0.047 & 0.016 & 0.003 \\
\hline Cereals*Other farm output & 0.036 & 0.012 & 0.003 \\
\hline Other crops* Other farm output & 0.009 & 0.007 & 0.233 \\
\hline Land $^{2}$ & -0.232 & 0.288 & 0.421 \\
\hline Labour $^{2}$ & -0.208 & 0.114 & 0.071 \\
\hline Capital2 & 0.107 & 0.052 & 0.039 \\
\hline Land*Labour & 0.426 & 0.142 & 0.003 \\
\hline Land*Capital & 0.020 & 0.094 & 0.829 \\
\hline Labour*Capital & -0.041 & 0.073 & 0.571 \\
\hline Time & 0.003 & 0.003 & 0.283 \\
\hline Time $^{2}$ & 0.011 & 0.001 & 0.000 \\
\hline Cereals*Time & 0.002 & 0.005 & 0.689 \\
\hline Other crops* Time & 0.001 & 0.004 & 0.812 \\
\hline Other farm output*Time & 0.003 & 0.002 & 0.180 \\
\hline Land*Time & -0.014 & 0.010 & 0.180 \\
\hline Labour*Time & 0.016 & 0.008 & 0.060 \\
\hline Capital*Time & 0.008 & 0.005 & 0.131 \\
\hline Cereals*Land & 0.067 & 0.069 & 0.332 \\
\hline Other crops*Land & -0.018 & 0.051 & 0.725 \\
\hline Other farm output*Land & -0.057 & 0.033 & 0.090 \\
\hline Cereals*Labour & 0.047 & 0.050 & 0.346 \\
\hline Other crops*Labour & -0.069 & 0.032 & 0.033 \\
\hline Other farm output*Labour & 0.023 & 0.024 & 0.353 \\
\hline Cereals*Capital & 0.019 & 0.028 & 0.496 \\
\hline Other crops ${ }^{*}$ Capital & 0.005 & 0.021 & 0.811 \\
\hline Other farm output*Capital & -0.014 & 0.014 & 0.319 \\
\hline LFA & -0.074 & 0.025 & 0.003 \\
\hline Year_2008 & -0.250 & 0.021 & 0.000 \\
\hline Constant & 0.083 & 0.029 & 0.004 \\
\hline
\end{tabular}

Source: author's calculations

Table 1: Parameter estimate.
First, we evaluate the farm production structure in our data set using the shadow shares of outputs. The results show high cereal specialization in the Czech Republic. The share of cereal output in the total output was $56 \%$, evaluated at the sample means and using the normalisation for the situation with constant returns to scale. The shadow share of other crop output is $29 \%$ and the third output accounts for $15 \%$. As far as the cost shares are concerned, we obtained expected results that are consistent with the information we have in our database. In particular, the highest cost share, 57\%, was estimated for material inputs. The other inputs (labour, capital and land) have similar shares, between $12 \%$ and $16 \%$. As far as economies of scale are concerned, we can conclude that the sample is characterized by an almost optimal size. That is, the average farm operates with almost constant returns to scale.

Technological change is positive and accelerates over time, evaluated on the sample mean. Moreover, we do reject Hicks-neutral technological change. The estimated biased technological change is landusing and labour- and capital-saving. This indicates a successful innovation activity for the sample farms, resulting in cost diminution - an important source of competitive advantage. Moreover, the magnitude of the labour-saving technological change, an example of which is machine-learning technology (for more examples, see Gallardo and Sauer, 2018), indicates the increasing prevalence of precision farming practises in cereal production. Furthermore, it reflects the real wage increase relative to the real rental rate of capital and confirms Hick's induced innovation hypothesis (Irmen, 2013).

The TFP was found to be increasing in the first half of the analysed period, between 2004 and 2012. The average annual growth was $3.4 \%$. However, the opposite is true for the second period, with an average annual decline of $2.4 \%$. That is, the average annual change in TFP over the analysed period is almost equal to zero. Figure 1 illustrates the estimated trends in the distribution of total factor productivity over time, and shows that the main source of TFP change was technological change (TC). Scale effect (SC) and technical efficiency (TE) do not contribute significantly to the TFP dynamics over the analysed period. These results are in line with a study by Bokusheva and Čechura (2017), who found that the TFP growth in French, British, and Czech cereal production was prompted by technological change in the period 2004-2013. This suggests that investments in information, sensor, and AI technologies can accelerate 


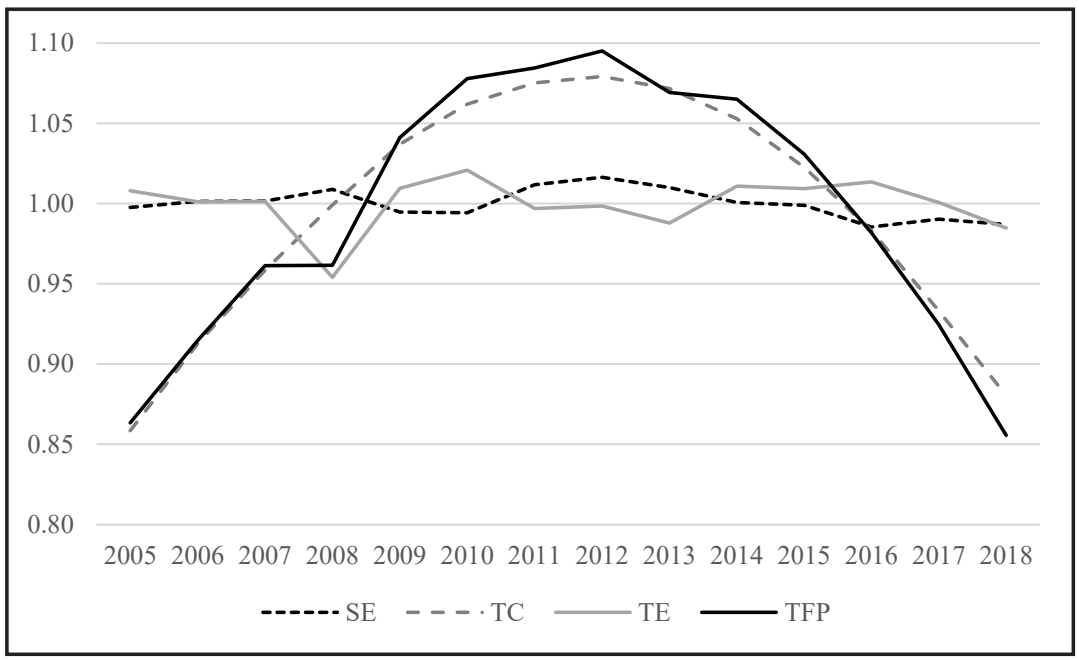

Source: author's calculations

Figure 1: Total factor productivity and its sources.

productivity and hence increase competitiveness. Consequently, and similarly to Kostlivý et al. (2020), we can conclude that agricultural policies for increasing productivity should concentrate on technological progress.

The initial strong positive technological change in the first half of the analysed period might be related to considerable increases in subsidies that resulted in higher investments. The support for this conclusion can be found in the development of the sample average depreciation. It is well known from the literature that subsidies may influence farm productivity through different channels, which might have a positive or negative impact. Subsidies may negatively impact productivity by causing allocative and technical inefficiency or soft-budget constraints (Kornai, 1986). On the other hand, they may improve the access of farms to innovative technologies and speed up technological change (Bezlepkina et al., 2005). The overall effect is a combination of these channels. Our results suggest that at least in the first period, Czech farmers took advantage of the opportunities of EU accession and improved their productivity by speeding up technological change.

If we concentrate on the comparison between precision and conventional farming, we cannot observe any significant differences, not even in productivity or technical efficiency evaluated on the sample mean. However, as Table 2 illustrates, despite the fact that we do not find significant differences in the mean of technical efficiency and total factor productivity, we can observe that variability is considerably lower in the group of farmers that use precision farming. In other words, if a farmer uses precision farming, then it is characterized by high technical efficiency. Moreover, from a dynamic perspective the farmers who started to use precision farming indicated an increase in technical efficiency. Moreover, they were characterized by higher technological change component as compared to conventional farming, evaluated on the sample mean.

\begin{tabular}{|l|c|c|c|c|}
\hline Whole sample & Mean & Std.Dev. & Minimum & Maximum \\
\hline $\begin{array}{l}\text { Overall technical } \\
\text { efficiency }\end{array}$ & 0.83 & 0.04 & 0.53 & 0.95 \\
$\begin{array}{l}\text { Persistent technical } \\
\text { efficiency }\end{array}$ & 0.91 & 0.03 & 0.65 & 0.98 \\
\hline $\begin{array}{l}\text { Transient technical } \\
\text { efficiency }\end{array}$ & 0.91 & 0.03 & 0.63 & 0.98 \\
\hline Precision farming & Mean & Std.Dev. & Minimum & Maximum \\
\hline $\begin{array}{l}\text { Overall technical } \\
\text { efficiency }\end{array}$ & 0.82 & 0.01 & 0.82 & 0.83 \\
\hline $\begin{array}{l}\text { Persistent technical } \\
\text { efficiency }\end{array}$ & 0.91 & 0.00 & 0.91 & 0.91 \\
$\begin{array}{l}\text { Transient technical } \\
\text { efficiency }\end{array}$ & 0.90 & 0.01 & 0.90 & 0.91 \\
\hline
\end{tabular}

Source: author's calculations

Table 2: Technical efficiency.

The estimated average value of overall technical efficiency $(83 \%)$, which is similar to the value estimated by Kostlivý et al. (2020), reveals that Czech cereal producers greatly exploit their production possibilities. The overall technical efficiency estimates indicate that, as evaluated at the sample averages, sample farms can reduce their costs by $5 \%$ up to $47 \%$. The average overall technical efficiency of precision farming is $82 \%$. The distribution is relatively dense and skewed toward higher values, indicating a cost reduction of $17 \%$ to $18 \%$. The persistent and transient technical efficiencies have a similar level, 91\% and $90 \%$, respectively, and also a similar distribution. 
In other words, systematic and unsystematic managerial failures have a similarly strong impact on the inefficiency of the transformation process in precision farming.

\section{Conclusion}

The aim of this paper was to investigate the sources of competitiveness in precision farming, and to evaluate the differences in productivity and technical efficiency between the group of farmers who use the technology of precision farming and the group of farmers who use standard conventional farming technology. Attention was focused on cereal production from 2005 to 2018 using FADN data. From a methodological point of view, the analysis was based on the currently most advanced approach to productivity and technical efficiency analysis. The main contribution of this paper is the empirical application of the recently developed four-error component model to the analysis of the efficiency of precision farming, along with a comparison to the efficiency of standard conventional farming technology, which fills the gap in economic research regarding the analysis of technical efficiency and productivity in precision farming.

The estimated IDF function revealed that $\mathrm{Czech}$ cereal production can be characterized by a high degree of specialization, high material intensity, and an almost optimal operational size. In the analysed period, cereal producers exhibited technological progress resulting in cost diminution. The innovation and modernization of production technology was primarily connected with technologies and practices that address specific labour as well as capital constraints.

Technological change was found to be the most important source of the total factor productivity dynamics in the analysed period. Especially between 2004 and 2012, technological progress led to total factor productivity growth of $3 \%$ annually. This initial strong positive technological change was probably considerably accelerated by subsidies that resulted in higher investments. That is, the results suggest that at least in the first period, cereal producers in the Czech Republic took advantage of the opportunities of EU accession and improved their productivity by speeding up technological change. Given the speed of technological change and the speed of technological obsolescence, the further focus of agricultural policy on investment support can be recommended, with the aim of increasing the productivity as well as the sustainability of cereal production.

Precision farming is the result of innovative approaches to agricultural production. The new technologies and techniques that it utilizes optimise agricultural production processes, increase yields and reduce economic as well as environmental costs. The optimization of input use is supposed to be converted into a decrease in technical inefficiency. Our study confirmed this statement by uncovering the high density of technical efficiency scores around the mean value in the group of farmers that use precision farming, pointing to the fact that there is a higher loss of resources in the group of companies with conventional technology.

\section{Acknowledgements}

The results are the part of the solution of project No. QK1920398 „Duality in Czech Agriculture: Advantage or Disadvantage for New Generation Agriculture?", supported by the Ministry of Agriculture of the Czech Republic, program ZEMĚ.

\section{Corresponding authors}

doc. Ing. Zdeňka Žáková Kroupová, Ph.D.

Department of Economics, Faculty of Economics and Management

Czech University of Life Sciences Prague, Kamycka 129, Prague - Suchdol, 165 00, Czech Republic

Phone: +420 224382 303, E-mail: kroupovaz@pef.czu.cz

\section{References}

[1] Addo, F. and Salhofer, K. (2019) "Determinants of Persistent and Transient Technical Efficiency of Austrian Crop Farms", Paper prepared for presentation at the 59 $9^{\text {th }}$ Annual Conference, Braunschweig, Germany, September 25-27, 2019 [Online]. Available: https://ageconsearch.umn. edu/record/292287/ [Accessed: 23 Jan. 2021]. DOI 10.22004/ag.econ.292287. 
[2] Arellano, M. and Bover, O. (1995) "Another look at the instrumental variable estimation of error-components models", Journal of Econometrics, Vol. 68, pp. 29-51. ISSN 0304-4076. DOI 10.1016/0304-4076(94)01642-D.

[3] Balafoutis, A., Beck, B., Fountas, S., Vangeyte, J., van der Wal, T., Soto, I., Gómez-Barbero, M., Barnes, A. and Eory, V. (2017) "Precision Agriculture Technologies Positively Contributing to GHG Emissions Mitigation, Farm Productivity and Economics", Sustainability, Vol. 9. ISSN 2071-1050. DOI 10.3390/su9081339.

[4] Bezlepkina, I. V., Oude Lansink, A. G. J. M. and Oskam, A. J. (2005) "Effects of subsidies in Russian dairy farming", Agricultural Economics, Vol. 33, No. 3, pp. 277-288. ISSN 0021-857X. DOI 10.1111/j.1574-0864.2005.00067.x.

[5] Blundell, R. and Bond, S. (1998) "Initial conditions and moment restrictions in dynamic panel data models", Journal of Econometrics, Vol. 87, pp. 115-143. ISSN 0304-4076. DOI 10.1016/S0304-4076(98)00009-8.

[6] Bokusheva, B. and Čechura, L. (2017) "Evaluating dynamics, sources and drivers of productivity growth at the farm level", OECD Food, Agriculture and Fisheries Papers, No. 106. Paris: OECD Publishing. E-ISSN 18156797. DOI 10.1787/5f2d0601-en.

[7] Caves, D. W., Christensen, L. R. and Diewert, W. E. (1982) "The Economic Theory of Index Numbers and the Measurement of Input, Output, and Productivity", Econometrica, Vol. 50, No. 6, pp. 13931414. ISSN 1468-0262. DOI 10.2307/1913388.

[8] Čechura, L., Grau, A., Hockmann, H., Levkovych, I. and Kroupová, Z. (2017) "Catching up or falling behind in Eastern European agriculture - the case of milk production", Journal of Agricultural Economics, Vol. 68, No. 1, pp. 206-227. ISSN 0021-857X. DOI 10.1111/1477-9552.12193.

[9] Čechura L., Kroupová Z. and Rudinskaya T. (2015) "Factors determining TFP changes in Czech agriculture", Agriculture Economics - Czech, Vol. 61, pp. 543-551. ISSN 1805-9295. DOI 10.17221/14/2015-AGRICECON.

[10] Chambers, R. G. (1988) "Applied Production Analysis", Cambridge: Cambridge University Press. 331 p. ISBN 0-521-31427-5.

[11] Cisternas, I., Velásquez, I., Caro, A. and Rodríguez, A. (2020) "Systematic literature review of implementations of precision agriculture", Computers and Electronics in Agriculture, Vol. 176, No. Sept, 105626. ISSN 0168-1699. DOI 10.1016/j.compag.2020.105626.

[12] Coelli, T. J., Rao, D. S. P., O’Donnell, Ch. J. and Battese, G. E. (2005) "An Introduction to Efficiency and Productivity Analysis", New York: Springer. 341 p. ISBN 987-0387-24265-1. DOI 10.1007/b136381.

[13] Colombi, R., Kumbhakar, S. C., Martini, G. and Vittadini, G. (2014) "Closed-skew normality in stochastic frontiers with individual effects and long/short-run efficiency", Journal of Productivity Analysis, Vol. 42, No. 2, pp. 123-136. ISSN 1573-0441. DOI 10.1007/s11123-014-0386-y.

[14] Diewert, W. (1976) "Exact and Superlative Index Numbers", Journal of Econometrics, Vol. 4, No. 2 , pp. 115-145. ISSN 0304-4076. DOI 10.1016/0304-4076(76)90009-9.

[15] Filippini, M. and Greene, W. H. (2016) "Persistent and Transient Productive Inefficiency: A Maximum Simulated Likelihood Approach", Journal of Productivity Analysis, Vol. 45, pp.187-196. ISSN 1573-0441. DOI 10.1007/s11123-015-0446-y.

[16] Finger, R., Swinton, S. M., El Benni, N. and Walter, A. (2019) "Precision farming at the nexus of agricultural production and the environment", Annual Review of Resource Economics, Vol. 11, pp. 1-23. ISSN 1941-1340. DOI 10.1146/annurev-resource-100518-093929.

[17] Foley, J. A., Ramankutty, N., Brauman, K. A., Cassidy, E. S., Gerber, J. S., Johnston, M., Mueller, N. D., O’Connell, Ch., Ray, D. K., West, P. C., Balzer, Ch., Bennett, E. M., Carpenter, S. R., Hill, J., Monfreda, Ch., Polasky, S., Rockström, J., Sheehan, J., Siebert, S., Tilman, D. and Zaks, D. P. M. (2011) "Solutions for a cultivated planet", Nature, Vol. 478, No. 7369, pp. 337-342. ISSN 1476-4687. DOI 10.1038/nature10452. 
[18] Gallardo, R.K., Sauer, J. (2018) "Adoption of Labor-Saving Technologies in Agriculture", Annual Review of Resource Economics, Vol. 10, pp. 185-206. ISSN 1941-1340. DOI 10.1146/annurev-resource-100517-023018.

[19] Gebbers, R. and Adamchuk, V. I. (2010) "Precision Agriculture and Food Security", Science, Vol. 327, No. 5967, pp. 828-831. ISSN 1095-9203. DOI 10.1126/science.1183899.

[20] Irmen, A. (2013) "Capital- and Labor-Saving Technical Change in an Aging Economy", International Economic Review, Vol. 58, No. 1., pp. 261-285. E-ISSN 1468-2354 DOI 10.1111/iere.12216.

[21] Jata, R. D., Jata, H. S., Nanwalb, R. K., Yadavc, A. K., Banad, A., Choudharye, K. M., Kakraliyab, S. K., Sutaliyaa, J. M., Sapkotaa, T. B. and Jat, M. L. (2018) "Conservation agriculture and precision nutrient management practices in maize-wheat system: Effects on crop and water productivity and economic profitability", Field Crops Research, Vol. 222, pp. 111-120. ISSN 0378-4290. DOI 10.1016/j.fcr.2018.03.025.

[22] Khanal, S., Fulton, J. and Shearer, S. (2017) "An overview of current and potential applications of thermal remote sensing in precision agriculture", Computers and Electronics in Agriculture, Vol. 139, pp. 22-2. ISSN 0168-1699. DOI 10.1016/j.compag.2017.05.001.

[23] Kornai, J. (1986) "The Soft Budget Constraint", Kyklos: International Review for Social Sciences, Vol. 39, No. 1, pp. 3-30. ISSN 1467-6435. DOI 10.1111/j.1467-6435.1986.tb01252.x.

[24] Kostlivý V., Fuksová Z. and Rudinskaya T. (2020) "Drivers of farm performance in Czech crop farms", Agriculture Economics - Czech, Vol. 66, pp. 297-306. ISSN 1805-9295. DOI 10.17221/231/2019-AGRICECON.

[25] Kumbhakar, S. C., Lien, G. and Hardaker, J. B. (2014) "Technical efficiency in competing panel data models: a study of Norwegian grain farming", Journal of Productivity Analysis, Vol. 41, No. 2, pp. 321-337. ISSN 1573-0441. DOI 10.1007/s11123-012-0303-1.

[26] Lien, G., Kumbhakar, S. C. and Alem, H. (2018) "Endogeneity, heterogeneity, and determinants of inefficiency in Norwegian crop-producing farms", International Journal of Production Economics, Vol. 201, pp. 53-61. ISSN 0925-5273. DOI 10.1016/j.ijpe.2018.04.023.

[27] Lovarelli, D., Bacenetti, J. and Guarino, M. (2020) "A review on dairy cattle farming: Is precision livestock farming the compromise for an environmental, economic and social sustainable production?", Journal of Cleaner Production, Vol. 262, 121409. ISSN 0959-6526. DOI 10.1016/j.jclepro.2020.121409.

[28] Loures, L., Chamizo, A., Ferreira, P., Loures, A., Castanho, R. and Panagopoulos, T. (2020) "Assessing the Effectiveness of Precision Agriculture Management Systems in Mediterranean Small Farms", Sustainability, Vol. 12, 3765. ISSN 2071-1050. DOI 10.3390/su12093765.

[29] Madau, F. A. (2007) "Technical Efficiency in Organic and Conventional Farming: Evidence form Italian Cereal Farms", Agricultural Economics Review, Vol. 8, No. 1, pp. 5-21. ISSN 1109-2580. DOI 10.22004/ag.econ.42141.

[30] Mankiw, N. G. (2009) "The principles of microeconomics", Mason: South-Western Cengage Learning, 545 p. ISBN 978-0-324-58998-6.

[31] Mintert, J., Widmar, D., Langemeier, M., Boehlje, M. and Erickson, B. (2016) "The challenges of precision agriculture: is big data the answer", Paper prepared for presentation at the Southern Agricultural Economics Association (SAEA) Annual Meeting, San Antonio, Texas, February 6-9, 2015. [Online]. Available: https://ageconsearch.umn.edu/record/230057/files/T\%20...\%20script_ SAEA_2016.pdf [Accessed: 22 Jan. 2021]. DOI 10.22004/ag.econ.230057.

[32] National Research Council (1997) "Precision Agriculture in the 21 $1^{\text {st }}$ Century: Geospatial and Information Technologies in Crop Management", Washington, D.C., USA: National Academy Press. ISBN 978-0309058933. DOI 10.17226/5491.

[33] Njuki, E., and Bravo-Ureta, B. E. (2015) "The Economic Costs of Environmental Regulation in U.S. Dairy Farming: A Directional Distance Function Approach", American Journal of Agricultural Economics, Vol. 97, No. 4, pp. 1087-1106. ISSN 1467-8276. DOI 10.1093/ajae/aav007. 
[34] Pisulewski, A. and Marzec, J. (2019) "Heterogeneity, transient and persistent technical efficiency of Polish crop farms", Spanish Journal of Agricultural Research, Vol. 17, No. 1. ISSN 2171-9292. DOI 10.5424/sjar/2019171-13926.

[35] Rudinskaya T., Hlavsa T. and Hruska M. (2019) "Estimation of technical efficiency of Czech farms operating in less favoured areas", Agriculture Economics - Czech, Vol. 65, pp. 445-453. ISSN 1805-9295. DOI 10.17221/52/2019-AGRICECON.

[36] Schrijver, R., Poppe, K. and Daheim, C. (2016) "Precision agriculture and the future of farming in Europe", Scientific Foresight Study IP/G/STOA/FWC/2013-1/Lot 7/SC5, Brussels: STOA, 38 p. ISBN 978-92-846-0475-3. DOI 10.2861/763030.

[37] Soto, I., Barnes, A., Balafoutis, A., Beck, B., Sánchez, B., Vangeyte, J., Fountas, S., Van der Wal, T., Eory, V. and Gómez-Barbero, M. (2019) "The contribution of Precision Agriculture Technologies to farm productivity and the mitigation of greenhouse gas emissions in the EU", JRC Technical Report, Luxembourg: Office of the European Union, 447 p. ISBN 978-92-79-92834-5. DOI $10.2760 / 016263$.

[38] Torkya, M. and Hassaneinb, A. E. (2020) "Integrating blockchain and the internet of things in precision agriculture: Analysis, opportunities, and challenges", Computers and Electronics in Agriculture, Vol. 178, 105476. ISSN 0168-1699. DOI 10.1016/j.compag.2020.105476.

[39] Tsionas, E. G. and Kumbhakar, S. C. (2014) "Firm heterogeneity, persistent and transient technical inefficiency: A generalized true random-effects model", Journal of Applied Econometrics, Vol. 29, No. 1, pp. 110-132. ISSN 1099-1255. DOI 10.1002/jae.2300.

[40] Zarco-Tejada, P. J., Hubbard, N. and Loudjani, P. (2014) "Precision Agriculture: an Opportunity for EU Farmers - Potential Support With the CAP 2014-2020", Study IP/B/AGRI/IC/2013_153, Brussels: European Parliament, 56 p. ISBN 978-92-823-5575-6.

[41] Zhang, N., Wang, M. and Wang, N. (2002) "Precision agriculture - a worldwide overview", Computers and Electronics in Agriculture, Vol. 36, No. 2-3, pp. 113-132. ISSN 0168-1699. DOI 10.1016/S0168-1699(02)00096-0. 